\title{
ANALISIS PENGENDALIAN INTERN TERHADAP PENJUALAN PADA PT. ARISTA CABANG PANJANG BANDAR LAMPUNG
}

\author{
Jhon Nasyaroeka \\ STIE Lampung \\ Rina Milyati \\ STIE Gentiaras \\ e-mail: rinamilyati@yahoo.com
}

\begin{abstract}
ABSTRAK
Analysis of intern restrain is process to reach one tools to cash sales although credit sales. Without intern restrain very good, company impossible to success. Sales account system is either analisys intern restrain. sales account system in the company to need cooperation between leader/manajer with white collar worker and sales system. Sales system take hold of actor important.therefore, analysis of intern restrain need to be corporate objective can be achieved.
\end{abstract}

Keywords: intern restrain, sales, sales account system

\section{PENDAHULUAN}

Perkembangan dunia usaha semakin berkembang, hal ini ditandai dengan semakin tajamnya persaingan dan banyaknya perusahaan baru yang bermunculan sehingga turut mendorong sektor usaha berkembang semakin kompleks dan lebih kompetitif. Oleh karena itu setiap dunia usaha harus mampu menyerap perkembangan ilmu pengetahuan, informasi dan mengoperasikan perusahaan secara efektif dan efisien agar tujuan perusahaan dapat tercapai. PT. ARISTA yang berada di daerah Panjang Bandar Lampung merupakan salah satu perusahaan industri yang bergerak dalam bidang otomotif.

Penjualan adalah aktivitas yang paling penting dan merupakan tujuan utama perusahaan yang dikelola dengan serius. Karena didalam kegiatan penjualan terkandung suatu harga dari barang yang dijual. Dan aktivitas penjualan merupakan jaminan hidup suatu perusahaan.
Pada umumnya tujuan didirikan suatu perusahaan adalah bermotif mencari keuntungan. Agar tujuan tersebut tercapai dan tidak terjadi hambatan yang mengakibatkan kerugian pada perusahaan maka aktivitas penjualan harus diperhatikan dan perlunya sistem penjualan yang apik.

Manajemen merupakan alat bantu dalam menjalankan tugasnya, sehingga tujuan perusahaan dapat tercapai. Dalam hal ini, selain perlu kecakapan seorang manager juga diperlukan adanya sistem informasi serta pengendalian intern yang baik, salah satu sintem informasi yang penting dalam suatu perusahaan sistem akuntansi atau organisasi administrasi. Untuk itu manajemen perusahaan perlu mengadakan internal chek atau pengendalian intern, salah satunya pengendalian terhadap penjualan. Hal ini dilakukan guna memperkecil penyimpangan yang terjadi sehingga tujuan perusahaan dapat tercapai secara efektif dan efisien.

Setiap perusahaan dalam melakukan penjualan tentu saja menginginkan laba yang cukup, 
apabila memungkinkan laba yang besar. Oleh karena itu perusahaan yang bergerak dalam bidang perdagangan haruslah dapat melaksanakan dan menetapkan sistem penjualan yang baik. Faktor penjualan yang berperan dalam sistem akuntansi penjualan adalah formulir, buku catatan, prosedur dan alat-alat yang digunakan untuk mengolah data yang berhubungan dengan usaha pada perusahaan tersebut.

\section{REVIEW LITERATUR DAN HIPOTESIS}

IAI (2001:319) mendefinisikan pengendalian intern sebagai suatu proses yang dijalankan oleh dewan komisaris, menejemen dan personel lain entitas yang didesain untuk memberikan keyakinan memadai tentang pencapaian: keandalan pelaporan keuangan, efektifitas dan efisiensi operasi dan kepatuhan terhadap hukum dan peraturan yang berlaku.

Standar Auditing Seksi Pertimbangan atas Pengendalian Intern dalam Audit Laporan Keuangan mendefinisikan pengendalian internal sebagai suatu proses yang dijalankan oleh dewan komisaris, manajemen, dan personel lain.

Tujuan pengendalian intern adalah untuk memberikan keyakinan memadai dalam pencapaian tiga golongan tujuan (Mulyadi, 2002):

- Keandalan informasi keuangan

Keandalan informasi keuangan yaitu untuk mempermudah bagian kasir dalam melakukan pencatatan-pencatatan transaksi-transaksi yang terjadi dalam perusahaan.

- Kepatuhan terhadap hukum dan peraturan yang berlaku

Yaitu: dalam perusahaan harus ada peraturan dan sangsi-sangsi hukuman yang berlaku dalam perusahaan supaya tidak terjadi kecurangan dalam pekerjaan.
- Efektivitas dan efisiensi operasi

Yaitu: setiap perusahaan harus ada efektifitas dan efisien pada karyawannya supaya tidak ada pemborosan waktu.

Karena tidak semua tujuan pengendalian intern tersebut relevan dengan audit atas laporan keuangan, tanggung jawab auditor dalam mematuhi standar pekerjaan lapangan kedua yang berbunyi:

"Pemahaman memadai atas pengendalian intern harus diperoleh untuk merencanakan audit dan menentukan sifat, saat, dan lingkup pengujian yang akan dilakukan". Oleh karena itu, auditor berkewajiban untuk memahami pengendalian intern yang ditujukan untuk memberikan keyakinan memadai bahwa laporan keuangan disajikan secara wajar sesuai dengan prinsip akuntansi berterima umum di Indonesia.

\section{Konsep Dasar Pengendalian Intern}

Menurut Amir Abadi Yusuf (2000 : 52), konsep dasar pengendalian intern :

Manajemen bertanggung jawab penuh terhadap penyajian laporan keuangan sesuai dengan standar akuntansi keuangan yang berlaku.

Dengan mempertimbangkan keterbatasanketerbatasan, biaya dan manfaat pengendalian, maka pengendalian intern dapat menberikan keyakinan yang memadai bukan absolute terhadap kewajaran laporan keuangan.

Efektifitas pengendalian intern sangat tergantung kepada kompetensi dan orang yang menggunakannya walaupun struktur pengendalian intern telah dirancang baik, tetapi pemakai sengaja berbuat kesalahan.

\section{Komponen Pengendalian Intern}

Pengendalian intern terdiri dari lima komponen yang saling berkaitan berikut ini : 
Lingkungan pengendalian terdiri dari tindakan, kebijakan, dan prosedur yang mencerminkan keseluruhan sikap dari menejemen puncak, para direktur dan pemilik dari suatu entitas mengenai pengendalian intern dan arti pentingnya bagi entitas itu.lingkungan pengendalian mencakup halhal berikut ini :

1. Integritas dan nilai-nilai etis

Adalah produk dari standar tingkah laku dan etis suatu entitas dan bagaimana mereka mengkomunikasikan dan diperkuat dengan praktek.

2. Komitmen untuk kompetensi

Adalah pengetahuan dan ketrampilan yang diperlakukan untuk menyelesaikan tugas yang mendefinisikan pekerjaan individual. Komitmen untuk kompetensi meliputi pertimbangan manajemen akan tingkat kompetensi untuk pekerjaan khusus dan bagaimana tingkat tersebut diterjemahkan dalam ketrampilandan pengetahuan yang diperlukan.

3. Partisipasi dewan direksi atau komite audit

Dewan direksi yang efektif adalah tidak terkait pada manajemen dan anggotanya dilibatkan dalam dan meneliti aktivitas manajemen Dewan mendelegasikan tanggung jawab untuk pengendalian intern kepada manajemen dan dibebankan untuk menyediakan panilaian independen secara teratur dari pengendalian intern yang dibuat manajemen

4. Filosofi dan gaya operasional manajemen Manajemen melalui aktifitasnya menyediakan isyarat yang jelas kepada karyawan tentang pentingnya pengendalian intern.

5. Struktur organisasi

Struktur organisasi entitas menggambarkan bentik tanggung jawab dan otoritas yang ada, dengna mempelajari struktur organisasi auditor dapat mempelajari manajemen dan unsur-unsur fungsional dari bisnis itu dan merasakan bagaimana kendali diterapkan.

6. Penugasan dari otorisasi dan tanggung Sebagai tambahan terhadap aspek komunikasi yang telah disebutkan, metode formal komunikasi jawab tentang otoritas dan tanggung jawab dan berbagai hal yang terkait dengan pengendalian yang serupa adalah sama pentingnya.

7. Kebijakan dan praktek SDM Aspek yang paling penting dari pengendalian intern adalah personal. Jika karyawan adalah orang yang kompeten dan bisa dipercaya, pengendalian lain bisa tidak ada dan laporan keuangan yang bisa diandalkan masih bisa dihasilkan.

\section{Penaksiran Resiko}

Resiko yang relevan dengan pelaporan keuangan mencakup peristiwa dan keadaan intern maupun ekstern yang dapat terjadi dan secara negative memengaruhi kemampuan entitas untuk mencatat, mengolah, meringkas dan melaporkan data keuangan konsisten dengan asersi manajemen dalam laporan keuangan.

Walaupun setiap organisasi memiliki pendekatan uniknya sendiri kepada manajemen resiko, laporan tersebut menekankan sejumlah langkah konsisten yang melambangkan praktek terbaik saat ini, langkah manajemen resiko termasuk :

Aktivitas pengendalian

Aktivitas pengendalian adalah kebijakan dan prosedur yang membantu memastikan bahwa arahan manajemen dilaksanakan. Aktifitas pengendalian mempunyai berbagai tujuan dan diterapkan diberbagai tingkat organisasi dan fungsi.

Sistem informasi yang relevan dengan tujuan pelaporan keuangan, yang meliputi sistem 
akuntansi, terdiri dari metode dan catatan yang dibangun untuk mencatat, mengolah, meringkas, dan melaporkan transaksi entitas (baik peristiwa maupun kondisi) dan untuk memelihara akuntabilitas bagi aktiva, utang, dan ekuitas yang bersangkutan.

\section{Sistem Akuntansi}

Sistem akuntansi adalah formulir-formulir, catatan-catatan, prosedur-prosedur, dan alat-alat yang digunakan untuk mengolah data mengenai usaha suatu kegiatan ekonomis dengan tujuan untuk menghasilkan umpan balik dalam bentuk laporan-laporan yang diperlukan oleh manajemen untuk mengawasi usahanya, dan bagi pihakpihak lain yang berkepentingan seperti pemegang saham, kreditor, dan lembaga-lembaga pemerintah untuk menilai hasil operasi.

Sistem akuntansi yang disusun harus mempunyai prinsip cepat yaitu sistem akuntansi harus mampu menyediakan data yang diperlukan tepat pada waktu, dapat memenuhi kebutuhan dan kualitas yang sesuai. Sistem akuntansi yang disusun harus mempunyai prinsip aman yaitu sistem akuntansi harus dapat membantu menjaga harta milik perusahaan dengan mempertimbangkan prinsip-prinsip pengawsan. Sistem akuntansi yang disusun harus memenuhi prinsip murah yaitu biaya untuk menyelenggarakan sistem akuntansi harus dapat ditekan sehingga relatif tidak mahal.

\section{Penjualan}

Aktivitas penjualan merupakan pendapatan utama perusahaan karena jika aktivitas penjualan produk maupun jasa tidak dikelola dengan baik maka secara langsung dapat merugikan perusahaan. Hal ini dapat disebabkan karena sasaran penjualan yang diharapkan tidak tercapai dan pendapatan pun akan berkurang. Penjualan merupakan salah satu sumber pendapatan peru- sahaan, jika semakin besar aktivitas penjualan disuatu perusahaan, maka akan semakin besar pula pendapatan yang akan diterima oleh perusahaan.

Penjualan Tunai adalah Penjualan yang bersifat cash dan carry pada umumnya terjadi secara kontan dan dapat pula terjadi pembayaran selama satu bulan dianggap kontan. Penjualan tunai merupakan penjualan dengan mengambil barang dari supplier dan langsung dikirim ke customer secara pembayaran langsung dengan menggunakan uang tunai. Sistem penjualan tunai pada umumnya didasarkan pada asumsi bahwa pembeli akan mengambil barang setelah harga barang dibayar ke kasir.

Penjualan kredit dilaksanakan oleh perusahaan dengan cara mengirimkan barang sesuai dengan order yang diterima sdari pembeli dan untuk jangka waktu tertentu perusahaan mempunyai tegihan kepada pembeli tersebut. Menurut Mulyadi (2006:232) laporan yang digunakan dalam penjualan kredit adalah laporan order penjualan, laporan pengiriman barang, laporan pencatatan piutang, laporan penagihan, dan laporan pencatatan penjualan. Sistem dan prosedur merupakan hal mutlak dan sangat diperlukan demi kelangsungan perusahaan. Oleh sebab itu sebelum melangkah lebih jauh ke bagian-bagian selanjutnya, sebaiknya kita harus memahami dulu apa yang dimaksud dengan sistem dan prosedur.

\section{METODE PENELITIAN}

Jenis penelitian yang dilakukan adalah dengan riset kepustakaan dan riset lapangan serta menggunakan alat analisis kualitatif. Waktu penelitian selama 2 bulan sejak bulan Februari 2011-Maret 2011. Dalam riset ini yang dijadikan populasi adalah sistem akuntansi penjualan tunai yang ditetapkan di PT. ARISTA Cabang Panjang Bandar Lampung Dalam pelaksanaan pengambilan sample penelitian yaitu penjualan barang da- 
gangan yang dilakukan oleh PT. ARISTA Cabang Panjang Bandar Lampung.

Untuk memperoleh data dan informasi yang akurat, maka penulisan teknik-teknik pengumpulan data sebagai berikut:

1. Studi Kepustakaan (Library Research)

Yaitu pengumpulan data melalui penelitian kepustakaan, dalam hal ini penulis mengadakan penelitian dengan cara membaca literatur-literatur manajemen, masalah, diktat, dan buku-buku lainnya yang berhubungan dengan pembahasan.

2. Studi Lapangnn (Field Research)

Yaitu teknik pengumpulan data dengan cara penelitian di lokasi perusahaan yang menjadi objek penelitian sebagai berikut :

a. Observasi

Yaitu mengadakan pengamatan secara langsung kepada objek penelitian dimana data-data dapat diperoleh.

b. Komunikasi

Yaitu mengadakan dialog (wawancara) langsung dengan pihak PT. ARISTA Cabang Panjang Bandar Lampung baik kepada pimpinan maupun karyawan.

Teknik analisis data yang digunakan adalah dengan membandingkan antara sistem penjualan yang digunakan atau diterapkan di PT. ARISTA Cabang Panjang Bandar Lampungdengan sistem akuntansi penjualan menurut teori.

\section{Analisis Data}

Bedasarkan data yang diperoleh penulis PT.ARISTA cabang Panjang,Bandar lampung.Sistem akuntansi penjualan dilakukan secara bulanan.Arsip-arsip penjualan yang disimpan,fungsinya untuk sewaktu-waktu dapat dikeluarkan kembali apabila diperlukan.Dalam sistem penjualan ini,perusahaan PT. Arista cabang Panjang ini melakukan dua cara penjualan yaitu penjualan tunai dan penjualan kredit.
Penjualan tunai adalah penjualan yang terjadi dimana penyerahan kendaraan dibayar dengan uang kontan atau pembayaran cek/giro selama tiga hari masih dianggap sebagai penjualan secara kontan, ini merupakan kebijaksanaan dari kepala cabang untuk mmeningkatan penjualan tunai.kelebihan dari penjualan tunai ini adalah perputaran uang menjadi semakin cepat,sehingga dana yang diperoleh dapat digunakan kembali untuk modal perusahaan,dengan demikian laba dapat meningkat.

Selain penjualan tunai PT. ARISTA cabang Panjang memberikan penjualan kredit yaitu penjualan yang diberikan perusahaan kepada konsumen dengan jangka waktu tertentu.Pada penjualan kredit ini pembayaran dapat dilakukan dengan berkala tergantung dari berapa lama konsumen mengambil jangka waktu pembayaran dengan bunga yang berbeda pula,dalam pembayaran kredit ini PT.Arista memberikan potongan-potongan harga agar konsumen lebih tertarik dalam melakukan kredit kendaraan.Adapun ketentuan perusahaan dalam memberikan kredit berdasarkan analisa administrasi keuangan,dengan meneliti status kredit pembeli bertujuan untuk menghindari tidak tertagihnya piutang.

Adapun prosedur penjualan kendaraan bermotor roda dua pada PT.Arista cabang Panjang adalah :

Prosedur penjualan tunai

Dalam prosedur penjualan tunai ini biasanya terjadi dengan cara konsumen datang langsung ke perusahaan untuk melihat barang yang sesuai dengan keinginan,setelah itu sales membuat SPK ( Surat Pesanan Kendaraan ) sebanyak empat rangkap yang diserahkan kepada bagian-bagian dengan ketentuan sebagai berikut :

- Lembar pertama diberikan pada konsumen.

- Lembar kedua diberikan ke bagian gudang.

- Lembar yang ketiga diberikan ke bagian Administrasi dan keuangan. 
- Lembar yang keempat diberikan kepada marketing.

Untuk pembayaran tunai ini setelah konsumen menandatangani faktur penjualan yang diberikan marketing,maka selanjutnyakonsumenmembayar kepada kasir sejumlah uang tertentu yang tertera pada faktur tersebut,kemudian bagian gudang menyiapkan kendaraan sesuai dengan pesanan dan bagian pengiriman mengirim kendaraan ke konsumen.

\section{Prosedur penjualan kredit}

Prosedurpenjualankredit inidilakukandengan mengunakan prosedur dan faktur yang terpisah. Dalam prosedur penjualan kredit ini konsumen dapat dilakukan dengan cara menghubungi pihak marketing atau dapat datang langsung ke PT.Arista cabang Panjang.Bagian marketing melakukan survei kondisi konsumen,setelah itu konsumen wajib memenuhi persyaratan yang diajukan pihak perusahaan.

Setelah konsep surat pesanan dibuat oleh bagian marketing yang kemudian dipindahkan ke dalam faktur penjualan rangkap empat dengan ketentuan sebagai berikut :

- Lembar pertama diarsipkan sementara oleh marketing,kemudian setelah diterima pembayaran diberikan kepada konsumen.

- Lembar kedua diberikan kepada bagian administrasi dan keuangan.

- Lembar ketiga diberikan kepada bagian gudang.

- Lembar keempat disimpan oleh bagian marketing.

Apabila setelah satu bulan dari pengiriman kendaraan maka marketing mengeluarkan faktur penjualan yang harus dibayar oleh konsumen setiap bulannya.Pembayaran tersebut dapat dilakukan dengan cara pembayaran tunai atau cek tunai. Setelah itu kasir menyetor uang ke bank.

\section{HASIL PENELITIAN DAN PEMBAHASAN}

Berdasarkan dari data informasi yang diperoleh oleh penulis dan telah diuraikan maka dalam hal ini akan dianalisis pengendalian intern penjualan yang dapat diterapkan dalam perusahaan sesuai dengan teori prosedur penjualan.

Dalam prosedur penjualan melibatkan beberapa bagian dalam perusahaan dengan maksud agar penjualan yang terjadi dapat diawasi dengan baik.Bagian-bagian yang terkait dalam prosedur penjualan adalah bagian gudang, bagian marketing,bagian kasir,bagian administrasi dan keuangan, dimana setiap fungsi memiliki peranan berbeda.

Berikut ini adalah penjelasan prosedur penjualan pada PT.Arista Cabang Panjang yaitu sebagai berikut :

- Bagian marketing menerima pesanan dari konsumen lalu membuat SPK (Surat Pesanan Kendaraan) rangkap empat kemudian diserahkan kepada kepala cabang untuk diotorisasi.

Lembar pertama diserahkan kepada konsumen,lembar kedua diserahkan kepada bagian gudang,lembar ketiga diserahkan kepada bagian administrasi dan keuangan dan lembar keempat bila konsumen melakukan pembelian dengan tunai atau kredit.bila konsumen membeli secara tunai maka SPK (Surat Pesanan Kendaraan) akan diserahkan kepada kasir,apabila secara kredit marketing membuat memo leasing sebanyak dua rangkap.Lembar pertama akan diserahkan kepada kasir dan lembar kedua akan diserahkan kepada bagian administrasi dan keuangan,lalu bila batal tidak terjadi transaksi.

- Bagian gudang menerima lembar kedua dari marketing dan bagian administrasi dan keuangan lalu bagian gudang menyiapkan barang dan mengecek mesin kendaraaan,dan 
lembar PDI diserahkan kembali ke bagian administrasi dan keuangan untuk membuat surat jalan.

- Bagian kasir menerima lembar pertama dari marketing bila terjadi pembelian kredit lalu bila terjadi pembelian tunai maka kasir membuat surat bukti pembayaran sebanyak tiga rangkap.Lembar pertama diserahkan kepada konsumen lalu lembar kedua dan ketiga diarsipkan agar sewaktu-waktu dapat dipakai bila diperlukan.

- Bagian administrasi dan keuangan menerima lembar ketiga dan kedua memo leasing dari marketing,dan menerima fotokopi KTP dari konsumen.yang akan diinputnama,alamat,tipe dan jenis kendaraan untuk dicetak sebanyak empat lembar,lembar pertama PDI dikirim kepada bagian gudang,lembar kedua,ketiga dan keempat diarsipkan.Aministrasi dan keuangan membuat surat jalan rangkap dua lalu diserahkan kepada kepala cabang untuk diotorisasi, setelah diotorisasi oleh kepala cabang lembar pertama diserahkan kepada supir utnuk mengirim barang ke konsumen.

Prosedur-prosedur pnjualan tunai menurut teori adalah sebagai berkut:

- Prosedur order penjualan

Dalam prosedur ini, bagian penjualan menerima order deri konsumen dan membuat faktur penjualan tunai untuk memungkinkan konsumen melakukan pembayaran harga barang ke bagian kassa dan untuk memungkinkan bagian gudang dan bagian pengiriman barang menyiapkan barang yang akan diserahkan kepada konsumen.

- Prosedur Penerimaan Kas

Dalam prosedur ini bagian kassa menerima pembayaran harga barang dari pembeli dan memberikan tanda pembayaran (berupa pita register kas dan cap "lunas" pada faktur penjualan tunai) kepada pembeli untuk memung- kinkan pembeli tersebut melakukan pengambilan barang yang dibelinya dari bagian pembelian barang.

- Prosedur Penyerahan Barang

Dalam prosedur ini bagian pengiriman barang menyerahkan barang kepada penbeli atas persetujuan pimpinan cabang melalui jasa sopir.

- Prosedur Pencatatan Penjualan Tunai

Dalam prosedur ini bagian jurnal, buku besar dan laporan melakukan pencatatan transaksi penjualan tunai dalam jurnal penjualan dan penerimaan kas. Disamping itu, bagian kartu persediaan barang yang dijual dalam kartu persediaan

- Prosedur Penyetoran Kas ke Bank

Sistem pengendalian intern terhadap kas mengharuskan penyetoran dengan segera ke Bank semua kas yang diterima dari penjualan tunai ke Bank harus dalam jumlah penuh.

- Prosedur Pencatatan Penerimaan Kas

Dalam prosedur ini, bagian jurnal, buku besar dan laporan mencatat penerimaan kas kedalam jurnal penerimaan kas bredasarkan bukti setoran kebagian Bank yang Rekapitulasi harga pokok penjualan ini, bagian kartu persedian dan kartu biaya membuat bukti memorial sebagian dokumen sumber untuk pencatatan harga pokok penjualan kadalam jurnal umum.

- Prosedur Pencatatan Harga Pokok Penjualan Dalam prosedur ini, bagian kartu persedian dan kartu biaya membuat Rekapitulasi harga pokok penjualan bardasarkan data yang dicatat dalam kartu persedian.Berdasarkan rekapitulasi harga pokok penjualan ini,bagian kartu persediaan dan kartu biaya membuat bukti memorial sebagai dokumen sumber untuk mencatat harga pokok penjualan umum.

Elemen sistem pengendalian intern dalam sistem penjualan kredit. 
a). Organisasi

(1). Fungsi penjualan harus terpisah dari fungsi pemberi otorisasi kredit.

(2). Fungsi pencatatan piutang harus terpisah dari fungsi penjualan dan fungsi pemberi otorisasi kredit.

(3). Fungsi pencatatan harus terpisah dari fungsi penerimaan kas.

(4). Transaksi penjualan kredit harus dilaksanakan oleh fungsi penjualan, fungsi pengiriman barang, fungsi penagihan, fungsi pencatatan piutang, dan fungsi akuntansi yang lain.

b). Sistem otorisasi dan prosedur pencatatan.

(1). Penerimaan order dari pembeli diotorisasi oleh fungsi penjualan dengan menggunakan formulir surat order pengiriman.

(2). Persetujuan pemberian kredit diberikan oleh pemberi otorisasi kredit dengan membubuhkan tanda tangan pada kredit copy ( yang merupakan tembusan surat order pengiriman )

(3). Pengiriman barang kepada pelanggan diotorisasi oleh fungsi pengiriman barang dengan cara menandatangani dan membubuhkan cap "sudah dikirim" pada copy surat order pengiriman.

(4). Penetapan harga jual, sarat penjualan, syarat pengangkutan barang dan potongan penjualan berada ditangan direktur pemasaran dengan penerbitan surat keputusan mengenai hal terseabut.

(5). Terjadinya piutang diotorisasi oleh fungsi penagihan dengan membubuhkan tanda tangan pada faktur penjualan.
(6). Pencatatan kedalam kartu piutang diotorisasi oleh fungsi pencatat piutang dan pencatat ke dalam jurnal penjualan, jurnal penerimaan kas, dan jurnal umum diotorisasi oleh fungsi akuntansi dengan cara memberikan tanda tanggan pada dokumen sumber (faktur penjualan, bukti kas masuk, dan memo kredit)

(7). Pencatatan terjadinya piutang didasarkan pada faktur penjualan yang didukung dengan surat order pengiriman dan surat muat.

Dengan demikian pencatatan prosedur harus didesain dengan baik dan benar, karena dalam suatu pencatatan harus memastikan bahwa pencatatan pengendalian mempunyai tujuan-tujuan yang akan dicapai, dengan cara mencatat transaksi yang tekah diotorisasi dengan benar, serta mencatat transaksi yang valid yang diserahkan dan dicatat sebagai aset, juga dicatat dari kehilangan ataupun pencurian, aktifitas bisnis yang dilaksanakan secara efisien dan efektif. 
Tabel hasil penelitian pada PT.ARISTA Cabang Panjang Bandar Lampung:

\begin{tabular}{|c|c|c|c|c|}
\hline No & Fungsi yang terkait & Menurut perusahaan & Menurut teori & Keterangan \\
\hline 1. & $\begin{array}{c}\text { Bagian pemasaran / } \\
\text { penjualan }\end{array}$ & $\begin{array}{l}\text { Menerima order dari } \\
\text { konsumen } \\
\text { - Mengisi faktur penjualan } \\
\text { tunai dan kredit sebanyak } 4 \\
\text { lembar }\end{array}$ & $\begin{array}{l}\text { - Menerima order dari } \\
\text { pembeli } \\
\text { - Mengisi faktur } \\
\text { penjualan tunai dan } \\
\text { kredit sebanyak } 3 \text { lembar }\end{array}$ & $\begin{array}{l}\text { - Tidak sesuai dengan } \\
\text { teori }\end{array}$ \\
\hline 2. & Bagian kassa & - Tidak ada & $\begin{array}{l}\text { - } \text { Menerima faktur } \\
\text { penjualan lembar kedua } \\
\text { - Menerima uang dari } \\
\text { pembeli / menerima } \\
\text { pembayaran dari mesin } \\
\text { ATM } \\
\text { - } \\
\text { Meregistrasikan } \\
\text { register kas dan } \\
\text { membutuh kan cap lunas }\end{array}$ & $\begin{array}{l}\text { - Tidak sesuai dengan } \\
\text { teori }\end{array}$ \\
\hline 3. & Bagian gudang & $\begin{array}{l}\text { Mengecek lembar } \\
\text { penjualan tunai dan kredit } \\
\text { dan menyiapkan barang } \\
\text { yang akan di kirim ke } \\
\text { konsumen bersama dengan } \\
\text { lembar satu dan dua dari } \\
\text { ADM(administrasi) }\end{array}$ & $\begin{array}{l}\text { Menyiapkan barang } \\
\text { dan menyerahkan } \\
\text { barang bersama lembar } \\
\text { penjualan tunai dan } \\
\text { kredit lembar ke dua }\end{array}$ & $\begin{array}{l}\text { - Tidak sesuai dengan } \\
\text { teori }\end{array}$ \\
\hline 4. & $\begin{array}{l}\text { Bagian pengiriman } \\
\text { barang / supir }\end{array}$ & $\begin{array}{l}\text { Mengrim pesanan dengan } \\
\text { membawa SPK (surat } \\
\text { pengiriman barang) lembar } \\
\text { satu dan dua yang telah di } \\
\text { setujui kepala cabang } \\
\text { - Pengiriman barang }\end{array}$ & $\begin{array}{l}\text { - Membawa lembar } \\
\text { satu yang di terima dari } \\
\text { bagian kassa untuk di } \\
\text { kirim ke pembeli } \\
\text { - Pengiriman barang }\end{array}$ & $\begin{array}{l}\text { - Tidak sesuai dengan } \\
\text { teori }\end{array}$ \\
\hline 5. & Bagian kasir & $\begin{array}{l}\text { Menerima faktur } \\
\text { penjualan tunai lembar ke } \\
\text { empat dan faktur penjualan } \\
\text { kredit lembar ke dua dari } \\
\text { bagian pemasaran } \\
\text { - Bagian kasir menyiapkan } \\
\text { faktu penjualan tunai dan } \\
\text { kredit lembar ke empat dan } \\
\text { ke dua }\end{array}$ & $\begin{array}{l}\text { Menerima faktur } \\
\text { penjualan tunai dan } \\
\text { kredit lembar pertama } \\
\text { dan membuat jurnal } \\
\text { penjualan } \\
\text { - Di arsipkan sesuai } \\
\text { dengan tanggal }\end{array}$ & $\begin{array}{l}\text { - Tidak sesuai dengan } \\
\text { teori }\end{array}$ \\
\hline
\end{tabular}


Seluruh sistem penjualan yang terdapat dalam perusahaan harus ada pertanggung jawabannya. Dalam organisasi setiap transaksi keuangan hanya akan terjadi jika telah dapat otorisasi dari yang barwenang. Otorisasi tersebut berwujud dalam bentuk tandatangan pada formulir,dengan demikian semua transaksi keuangan yang terjadi dalam perusahaan dapat di awasi menggunakan formulir yang telah diotorisasi sehingga transaksi dapat berjalan dengan baik.

Fungsi yang ada di teori namun tidak diterapkan pada PT.Arista Cabang Panjang Bandar Lampung adalah sebagai berikut:

- Bagian Gudang

Bagian pengecekanmesin dan pengeluaran plat (R2) pada PT.Arista Cabang Panjang merangkap ke bagian gudang.

- Bagian Kasir

Bagian kasir merangkap ke bagian piutang, bagian jurnal, bagian accounting, dan bagian kartu persediaan.

\section{KESIMPULAN DAN SARAN}

\section{Kesimpulan}

Berdasarkan pengolahan data dan analisis data tentang sistem akuntansi penjualan pada PT ARISTA CABANG PANJANG BANDAR LAMPUNG maka dapat di simpulkan sebagai berikut :

Sistem akuntansi penjualan pada PT. ARISTA CABANG PANJANG BANDAR LAMPUNG tidak banyak bagian atau fungsi yang bekerja karena bagian pengecekan mesin dan pengeluaran plat (R2) merangkap ke bagian gudang, bagian kasir merangkap bagian piutang, bagian jurnal, bagian accounting, dan bagian kartu persediaan.

Dengan adanya perangkapan tugas di beberapa fungsi tersebut maka sulit untuk menerapkan suatu pengendalian intern yang baik, di mana unsur penilaian pengendalian intern salah satunya dari sistem akuntansi yang ada salah satunya adalah sistem akuntansi penjualan.

\section{Saran}

Dari data yang di dapatkan pada PT ARISTA CABANG PANJANG BANDAR LAMPUNG, maka penulis dapat memberikan saran kepada perusahaan yaitu :

Sistem akuntansi penjualan yang di terapkan sudah cukup baik tetapi harus lebih di tingkatkan lagi. Pengendalaian intern yang ketat dari pimpinan harus lebih di perhatikan supaya tidak terjadi kecurangan pada perusahaan yang mengakibatkan kerugian. Dengan sistem akuntansi yang baik maka perusahaan mencapai tujuan dan kontinuitas serta kesejahteraan karyawan terjamin. Adapun saran yang penulis berikan berupa analisis sistem akuntansi penjualan secara tunai dan kredit yang dapat di terapkan dalam PT ARISTA CABANG PANJANG BANDAR LAMPUNG.

\section{DAFTAR PUSTAKA}

Ikatan Akuntansi Indonesia,2000,"Standar Akuntansi Keuangan" Jakarta : Salemba empat.

Mulyadi, 2002, "Pemeriksaan Akuntansi”, STIE YKPN, Yogyakarta.

Mulyadi, 2003, "Sistem Akuntansi”, STIE YKPN, Yogyakarta.

Wilkoinson, Joseph.w. 1992, "Sistem Akuntansi dan Informasi", Edisi ke 2, Erlangga, Jakarta. 